\title{
Level of School Bullying among Victims of Primary School Students at AL- Nasiriya City Center
}

مستوى التنمر المدرسي بين ضحايا طلاب المدارس الابتدائية في مركز مدينة الناصرية https://doi.org/10.32792/utq/utj/vol10/3/3

Mohammad F.Ali, MSc.*

Ali K. Khudhair, $\mathrm{PhD}^{* *}$

* Psychiatric Nursing student

** Assist. Professor, Mental Health Nursing Department, College of Nursing,

University of Karbala

mohammed.alsarafy@yahoo.com

alialjbori@yahoo.com

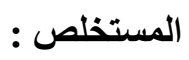

الهدف: لتقييم مستوى التنمر الددرسي بين ضحايا طلاب المدارس الابتدائية في مركز مدينة الناصرية والصفات

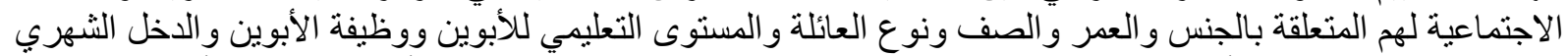

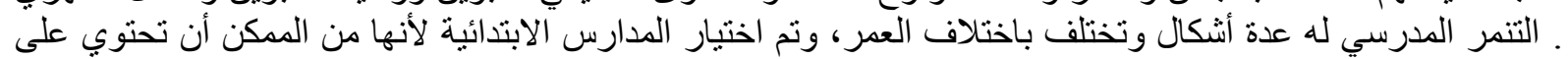

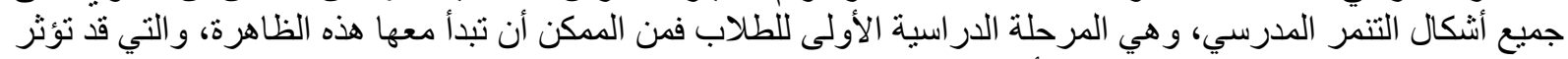

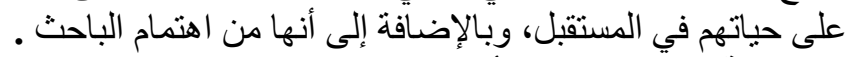

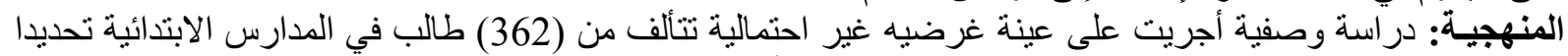

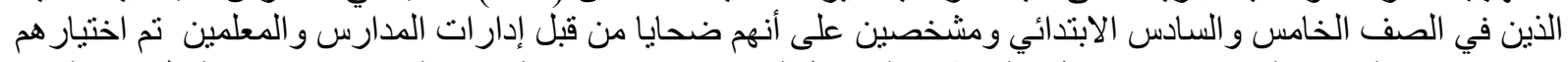

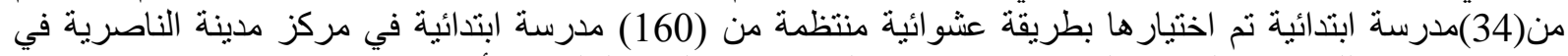

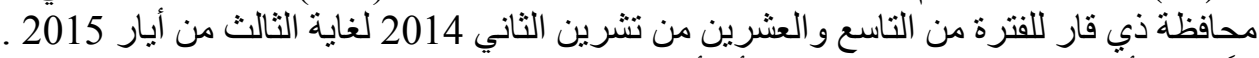

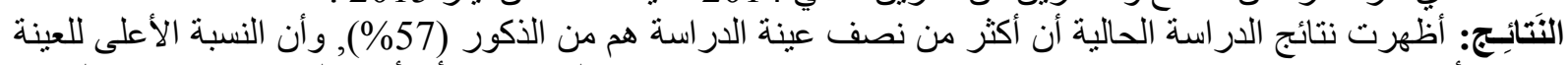

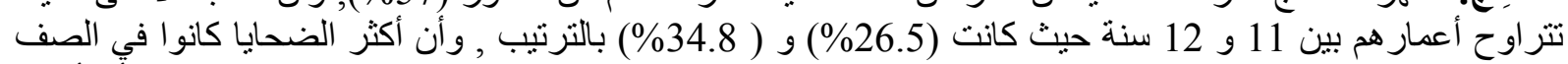

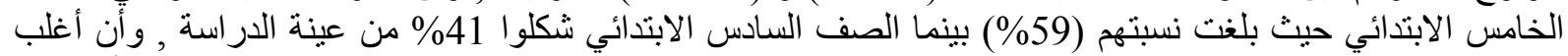

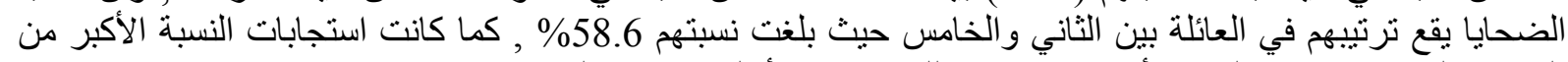

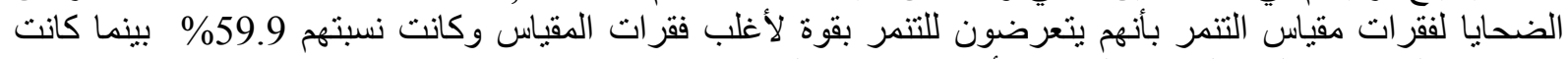

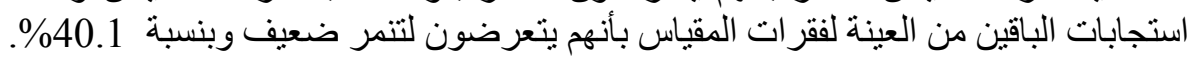

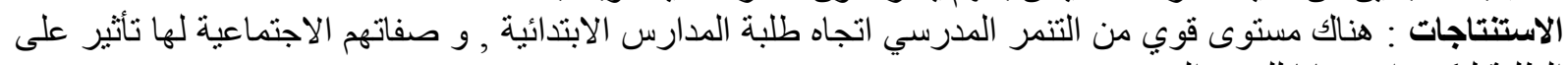

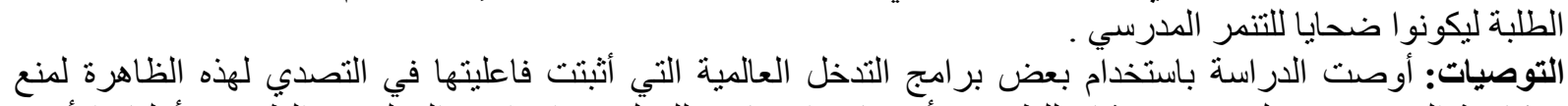

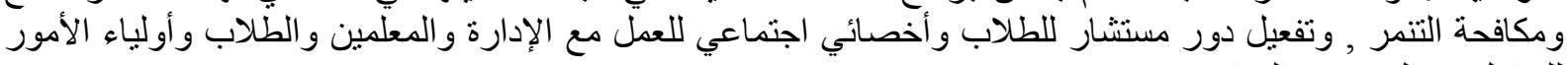

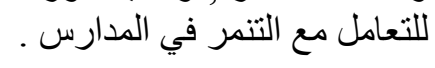

\section{Abstract:}

Objective: to assess the level of school bullying among victims of primary school students at AL- Nasiriya City Center and their demographic data such as age, gender, grade level, type of family, parents level of education, parents occupation, and monthly income . School bullying has several forms and vary depending on the age, and were selected primary schools because it is possible that contain all forms of school bullying, and it is the first school stage to the students it is possible to start with the phenomenon, which may affect their lives in the future, and in addition to that it is researcher's interest . 


\section{University of Thi-Qar Journal Vol.10 No.3 SEP 2015}

Web Site: https://jutq.utq.edu.iq/index.php/main Email: journal@jutq.utq.edu.iq

Methodology: A descriptive study was carried out on Non-probability (purposive) sample of 362 students in primary schools accurately $5^{\mathrm{TH}}$ and $6^{\mathrm{TH}}$ grade diagnosed as victims by the administers and teachers of a sample of 34 primary schools were selected systemic randomly from a total 160 schools at Al Nasiriya City Center in Thi-Qar Governorate.

Results The results of the current study appeared that more than half of the study sample $(57 \%)$ are males, and the highest percentages(26.5\%)and $(34.8 \%)$ of the sample was between the ages of 11 and 12 years respectively, and more victims were in the fifth grade where their proportion was $(59 \%)$, while the sixth grade was $(41 \%)$ of the study sample, and that most of victims $(58.6 \%)$ was arrange in the family between $\left(2^{\text {nd }}-5^{\text {th }}\right)$, and the largest percentage of responses to the paragraphs of victims scale that they were being bullied strongly for most of the items of the scale and their proportion was (59.9\%) while the remaining of the study sample responses to the items of the scale that they were exposed to bullying weakly and their proportion was $40.1 \%$.

Conclusions : There is strong level of bullying against primary school students, student's demographic data have affect on there to be victims of school bullying .

Recommendations: The present study recommends using some global intervention programs that confirmed its effectiveness in addressing the phenomenon to prevent and combat bullying, and activating the role of the student advisor and social worker to work with the administration, teachers, students and parents to deal with school bullying .

\section{Keywords: School Bullying; Victims; Primary school student}

\section{Introduction}

Bullying is commonly defined as deliberately harmful behavior, repeated over a period of time, by a person or group, who target and victimize a person in a less powerful position , bullying behavior can include physical or verbal assaults or indirect actions such as psychological manipulation, bullying can occur in any context where people interact with one another. This includes schools, workplaces, within the family and in neighborhoods. At a widely level, bullying can exist between social groups and between nations. at last, it is the deliberate, abuse and imbalance of power in relationships . (1)

Bullying is a group phenomenon within which children play a variety of the roles, including that of aggressor, victim, observer, defender and bully-victim . (2)

Bullying exists in all countries regardless of the cultural, political, and religious background, with similar frequency and trends in most schools . (3)

Bullying affects about 1 in 5 school-aged children in many different countries. Involvement in bullying (as perpetrators or victims) has negative effects on the physical and psychological health of children and on their future psychosocial adjustment as adults . (4)

School bullying is a worldwide problem that can have negative consequences for the general school climate and for the right of students to learn in a safe environment without fear, also the bullying could be have negative permanent consequences both for students who bully and for their victims, because that the incidents of bullying experienced by young children and adolescents in schools have become the focal point of international studies in the last quarter century . (5) 


\section{University of Thi-Qar Journal Vol.10 No.3 SEP 2015}

\section{Web Site: https://jutq.utq.edu.iq/index.php/main Email: journal@jutq.utq.edu.iq}

Peer relations are especially important in the young children and adolescents. One of the principal developmental processes in this period is the gradual gaining of the personal autonomy from one's parents precisely through such peer relationships. Problems with peers, as bullying, are likely to interfere with this important developmental process . (6)

The bullying is characterized by two conflicting parties that are imbalanced in terms of power; physically and/or mentally, what lies in the center of the bullying. It is an imbalance of power. The students who are physically stronger, more aggressive, more courageous, and physically more active, have an intrinsic tendency to bully. While, those students who are physically and emotionally weaker, more reserved, more humble and no hurtful are likely to be the victims. The victims have a tendency to be calm and inactive, and have only few friends. The victims are unable to effectively respond to aggressive behavior of the others and are inhibited and would not tell about being bullied to an adult or wait for a long time to do that. (7)

Bullying is comprised of direct behaviors such as taunting, teasing, threatening, and hitting initiated by one or more students against a victim and indirect behaviors such as isolating a student through deliberate exclusion. Whereas boys typically engage in direct bullying methods (physical), girls are more appropriate to utilize more subtle indirect methods (verbal and social exclusion), such as spreading rumors and enforcing social isolation . (8)

\section{Methodology:}

A descriptive study was carried out on 362students who study in primary schools of ALNasiriya City Center in Thi-Qar Governorate were selected according specific criteria :

\section{Inclusion Criteria are:}

$1.5^{\text {th }}$, and $6^{\text {th }}$ grade primary school students .

2. Both gender .

3. diagnosed as victims according to primary schools administers and teachers .

\section{Exclusion Criteria are:}

1.Students who doesn't complete the questionnaire .

2. Students who are from outside the city .

3. Students who have physical disability .

\section{Instrument :}

Data were collected through using a questionnaire is constructed after extensive review of available literature and related studies. The study instrument consists of two parts; The first part includes participants' demographic characteristics of age, gender, grade level, arrangement in family, parents level of education, parents occupation. The second part is related to bullying phenomenon used to identify victims of the bullying Victims Bullying Scale (V. B. S) adopted from Mostafa (9) who designed and developed it to measure victim of bullying.

Data were collected by the researcher from students who were attending primary schools at AL-Nasiriya city center in Thi-Qar Governorate through interview and by filling a questionnaire format.

Reliability of the questionnaire is determined through: pilot study "test-retest" which has been (0.81) whereas the validity was determined through a panel of experts in the field of mental health.(10) 
The demographic characteristic were obtained through a direct interview with each students in the study used, adopted and developed questionnaire format. The data collection process had been performed for the period from February, $15^{\text {th }}$ until March, $25^{\text {th }}, 2015$.

A statistical analysis was performed using the SPSS package (version 19). which include the following :
a. Frequencies $(\mathrm{F})$,
b. Percentages $(\%)$.
c. Graphic :

- Pie - chart

- Bar chart

d. Mean of score (MS)

In bullying domain the measure in the present study was based on cutoff point 1.5 due to the two points likert scales with two levels including: Strong = (mean of score equal or more than 1.5),weak (mean of score less than 1.5).

\section{Administrative Arrangements:}

An official permission was obtained from the Ministry of Planning / Central Statistical Organization (CSO) for the acceptance of the questionnaire draft .

And initial agreements of Ministry of Education, Directorate of Education in Thi-Qar Governorate in order to collect the required data each subjects students . 
University of Thi-Qar Journal Vol.10 No.3 SEP 2015

Web Site: https://jutq.utq.edu.iq/index.php/main Email: journal@jutq.utq.edu.iq

\section{Results:}

Table 1. Summary Statistics of Frequencies, Percentages of the students' Family Demographic Data.

\begin{tabular}{|c|c|c|c|c|}
\hline $\mathrm{T}$ & Demographic data & Rating & F. & $\%$ \\
\hline \multirow[t]{2}{*}{ 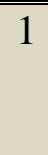 } & \multirow{2}{*}{ Type of family } & Nuclear Family & 277 & 76.5 \\
\hline & & Extended Family & 85 & 23.5 \\
\hline \multirow[t]{2}{*}{2} & \multirow{2}{*}{$\begin{array}{c}\text { Number of Family } \\
\text { Member }\end{array}$} & $\leq 3$ & 2 & 0.6 \\
\hline & & $4-8$ & 243 & $\bar{~} 67.1$ \\
\hline
\end{tabular}

$(\mathrm{N}=362)$ 
University of Thi-Qar Journal Vol.10 No.3 SEP 2015

Web Site: https://jutq.utq.edu.iq/index.php/main Email: journal@jutq.utq.edu.iq

\begin{tabular}{|c|c|c|c|c|}
\hline & & $10-14$ & 98 & 27.1 \\
\hline & & $15-20$ & 12 & 3.3 \\
\hline & & $20+$ & $\overline{7}$ & 1.9 \\
\hline \multirow[t]{5}{*}{3} & \multirow{5}{*}{$\begin{array}{l}\text { Number of Children in the } \\
\text { family }\end{array}$} & $\overline{\leq 1}$ & 15 & 4.1 \\
\hline & & $2-5$ & 200 & 55.2 \\
\hline & & $6-8$ & 136 & 37.6 \\
\hline & & $9-12$ & $\overline{6}$ & 1.7 \\
\hline & & $12+$ & 5 & 1.4 \\
\hline \multirow[t]{4}{*}{4} & \multirow{4}{*}{ Father Level of Education } & Primary School & 224 & 61.9 \\
\hline & & Secondary School & 55 & 15.2 \\
\hline & & Institute & 29 & 8 \\
\hline & & College And Above & 54 & 14.9 \\
\hline
\end{tabular}


University of Thi-Qar Journal Vol.10 No.3 SEP 2015

Web Site: https://jutq.utq.edu.iq/index.php/main Email: journal@jutq.utq.edu.iq

\begin{tabular}{|c|c|c|c|c|}
\hline \multirow[t]{4}{*}{5} & \multirow{4}{*}{ Mother Level of Education } & Primary School & 254 & 70.2 \\
\hline & & Secondary School & 39 & 10.8 \\
\hline & & Institute & 36 & 9.9 \\
\hline & & College And Above & 33 & 9.1 \\
\hline \multirow[t]{3}{*}{6} & \multirow{3}{*}{ Father Occupation } & Unemployed & 154 & 42.5 \\
\hline & & Employed & 175 & 48.3 \\
\hline & & Retired & 33 & 99.1 \\
\hline \multirow[t]{3}{*}{7} & \multirow{3}{*}{ Mother Occupation } & Housewife & 304 & 84 \\
\hline & & Employee & 53 & 14.6 \\
\hline & & Others & 5 & 1.4 \\
\hline
\end{tabular}

Table 1 continued .... 
University of Thi-Qar Journal Vol.10 No.3 SEP 2015

Web Site: https://jutq.utq.edu.iq/index.php/main Email: journal@jutq.utq.edu.iq

\begin{tabular}{|c||c|c|c|c||}
\hline 8 & \multirow{3}{*}{ Monthly Income } & Sufficient & 98 & 27.1 \\
\cline { 3 - 5 } & & Rarely sufficient & 91 & 25.1 \\
\cline { 3 - 5 } & & Insufficient & 173 & 47.8 \\
\hline
\end{tabular}

\section{F. Frequency $\%=$ percentage $\quad \mathrm{N}=$ participants}

The results appear that $76.5 \%$ of the study subjects are lived in a nuclear family, $67.1 \%$ of them are lived in family with 4-8 members, 55.2\% of them are lived in family with 2-4 children. In addition, $61.9 \%$ and $70.2 \%$ of fathers and mothers respectively are below preparatory school graduate . Regarding parents occupational status, the results indicate that $48.3 \%$ of fathers are employed, and $84 \%$ of mothers are housewives. Finally, the study results indicate that $47.8 \%$ of the study subjects are reported that their family monthly income is insufficient.

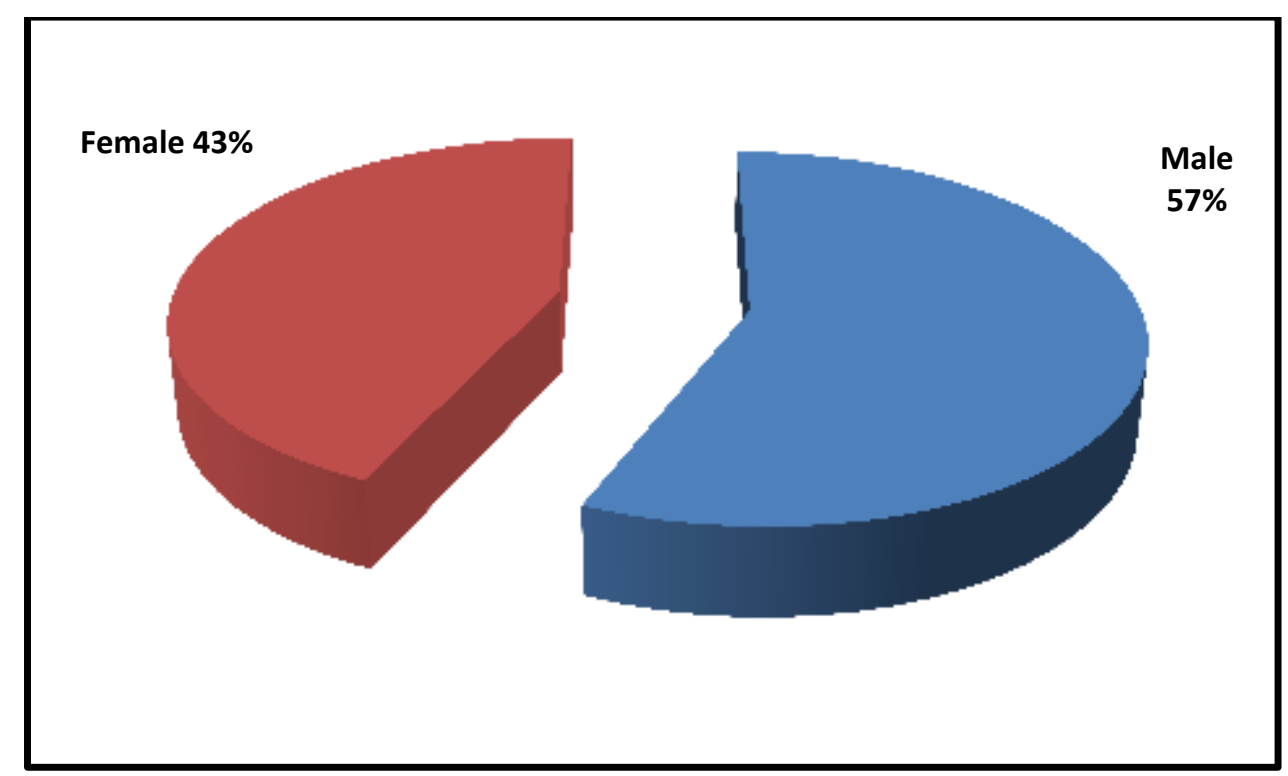

Figure 1: Distribution of the study sample according to their gender 
University of Thi-Qar Journal Vol.10 No.3 SEP 2015

Web Site: https://jutq.utq.edu.iq/index.php/main Email: journal@jutq.utq.edu.iq

The results appear that more than half of the study sample (57\%) are males.

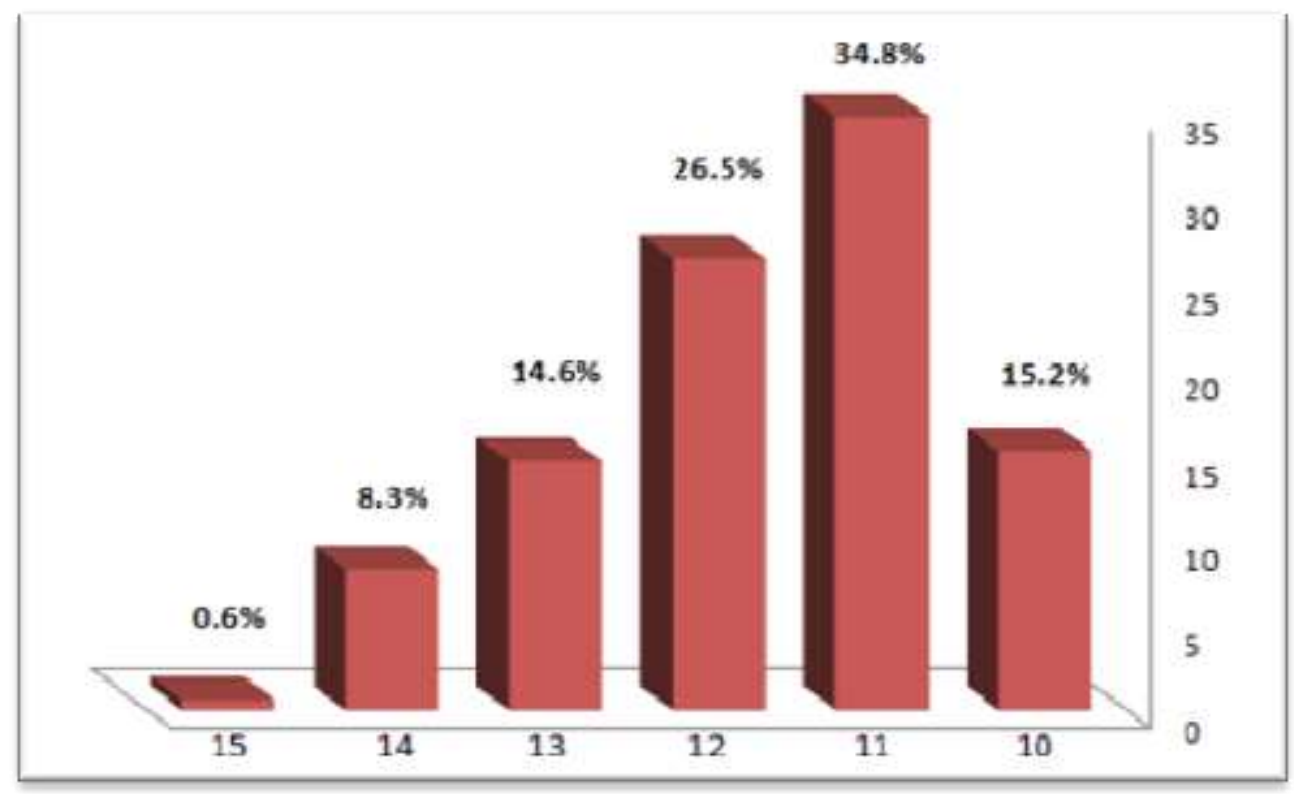

Figure 2: Distribution of the study sample according to their age

The results appear that the highest percentage of the study sample (26.5\%),(34.8\%) are between the age 11 and 12 years respectively .

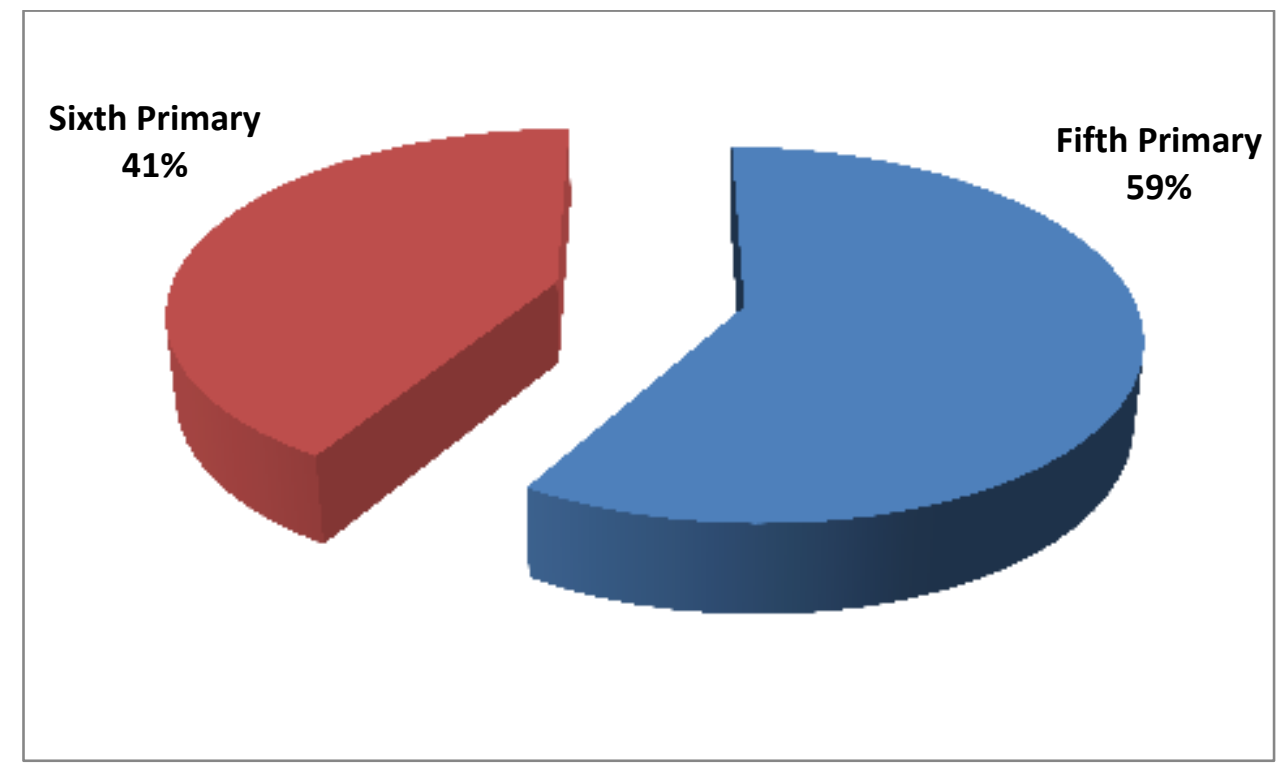

Figure 3 : Distribution of the study sample according to their grade 
University of Thi-Qar Journal Vol.10 No.3 SEP 2015

Web Site: https://jutq.utq.edu.iq/index.php/main Email: journal@jutq.utq.edu.iq

The figure appear that more than half (59\%) of the study sample are from $5^{\text {th }}$ grade.

\begin{tabular}{|l||c||c||c||c||c|c|}
\hline \multirow{2}{*}{$\mathrm{t}$} & Bullying items & $\mathrm{R}$ & $\mathrm{F}$. & $\%$ & $\mathrm{~m} . \mathrm{s}$ & $\mathrm{L}$ \\
\hline
\end{tabular}

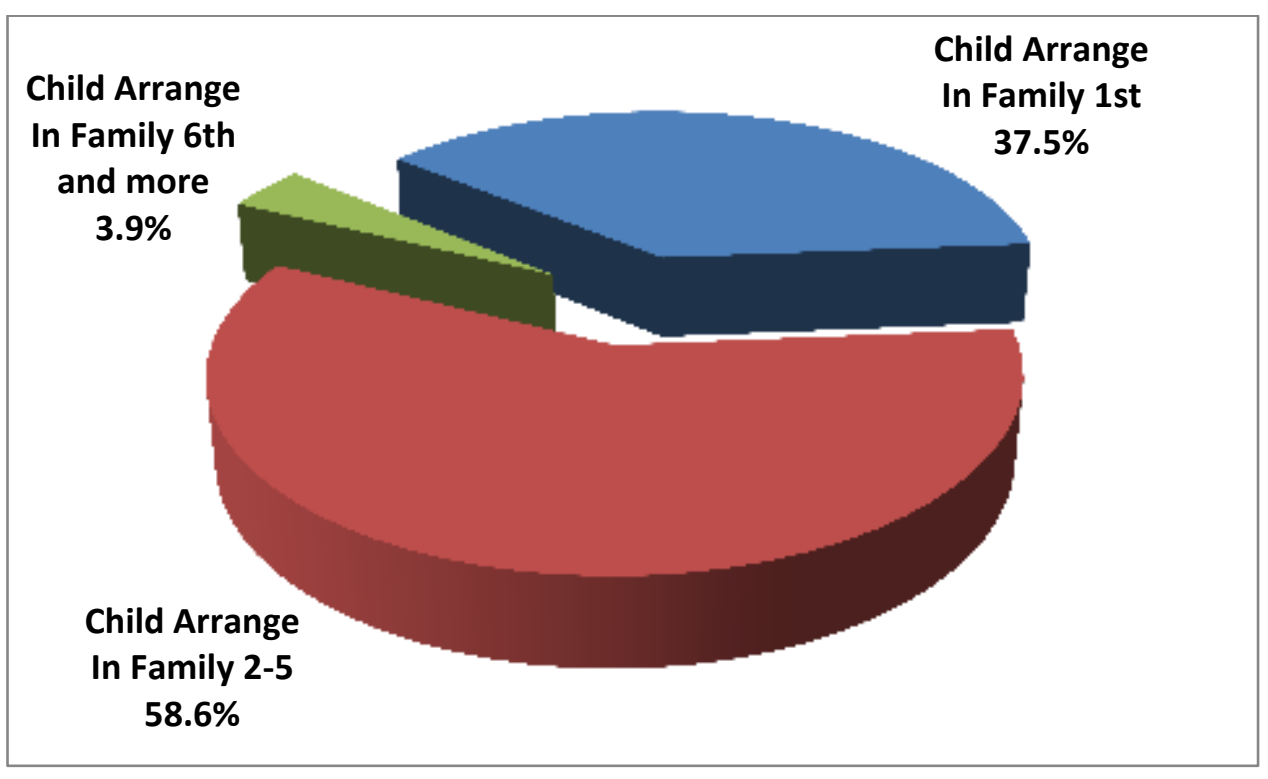

Figure 4 : Distribution of the study sample according to their arrangement

The results appear that most of the subjects are within $2-5^{\text {th }}$ in the arrangement of their brothers and sisters.

Table 2.The levels of bullying behaviors among victims of school students 
University of Thi-Qar Journal Vol.10 No.3 SEP 2015

Web Site: https://jutq.utq.edu.iq/index.php/main Email: journal@jutq.utq.edu.iq

\begin{tabular}{|c|c|c|c|c|c|c|}
\hline & Some of my colleagues hit, kick and push me & No & 114 & 31.5 & & \\
\hline & \multirow{2}{*}{ I was bitten or disk from some of my colleagues } & $\mathrm{No}^{\mathrm{Y} \overline{\mathrm{es}}}$ & 5248 & 988.5 & & \\
\hline 18 & & & 10 & 40.41 . & & \\
\hline \multicolumn{2}{|r|}{ My colleague disclosed my secrets to dispute me } & $\sqrt{\mathrm{No}}$ & \multicolumn{2}{|c|}{$2168^{6} \cdot 346.4^{1.6}$} & & \\
\hline 3 & teased in a hurtful way & Yes & 194 & 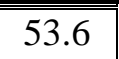 & & \\
\hline \multirow[b]{2}{*}{4} & \multirow{2}{*}{$\begin{array}{l}\text { Other students told lies or spread false rumors } \\
\text { about me and tried to make others dislike me }\end{array}$} & No & 160 & 44.2 & \multirow{2}{*}{1.60} & \multirow{2}{*}{$\mathrm{S}$} \\
\hline & & Yes & 202 & 55.8 & & \\
\hline \multirow[b]{2}{*}{5} & \multirow{2}{*}{$\begin{array}{c}\text { Some of my colleagues forced me to see some } \\
\text { pictures shameful against my will }\end{array}$} & No & 272 & 75.1 & \multirow{2}{*}{1.25} & \multirow{2}{*}{$\mathrm{W}$} \\
\hline & & Yes & 90 & 24.9 & & \\
\hline \multirow[b]{2}{*}{6} & \multirow{2}{*}{ I had things taken away from me or damaged } & No & 218 & 60.2 & \multirow{2}{*}{1.40} & \multirow{2}{*}{$\mathrm{W}$} \\
\hline & & Yes & 144 & 39.8 & & \\
\hline \multirow[b]{2}{*}{7} & \multirow{2}{*}{$\begin{array}{l}\text { I was called mean names or teased in a hurtful } \\
\text { way }\end{array}$} & No & 149 & 41.2 & \multirow{2}{*}{1.59} & \multirow{2}{*}{$\mathrm{S}$} \\
\hline & & Yes & 213 & 58.8 & & \\
\hline \multirow[b]{2}{*}{8} & \multirow{2}{*}{ Some of my colleagues dispute me for no reason } & No & 170 & 47 & \multirow{2}{*}{1.53} & \multirow{2}{*}{$\mathrm{S}$} \\
\hline & & Yes & 192 & 53 & & \\
\hline \multirow[b]{2}{*}{9} & \multirow{2}{*}{$\begin{array}{c}\text { I was tighten and pull my clothes by some of my } \\
\text { colleagues }\end{array}$} & No & 238 & 65.7 & \multirow{2}{*}{1.34} & \multirow{2}{*}{$\mathrm{W}$} \\
\hline & & Yes & 124 & 34.3 & & \\
\hline \multirow[b]{2}{*}{10} & \multirow{2}{*}{$\begin{array}{c}\text { Some of my colleagues puts obstacles in front of } \\
\text { me to spoil any work I do }\end{array}$} & No & 273 & 75.4 & 105 & $\mathbf{W}$ \\
\hline & & Yes & 89 & 24.6 & 1.25 & $\mathbf{W}$ \\
\hline & Some of my colleagues looked at me with & No & 201 & 55.5 & 144 & Wu \\
\hline 11 & contempt & Yes & 161 & 44.5 & 1.44 & $\mathrm{w}$ \\
\hline & Some of my colleagues take my properties by & No & 235 & 64.9 & 135 & $\mathrm{~W}$ \\
\hline 12 & force & Yes & 127 & 35.1 & $1.3 J$ & \\
\hline & Some of my colleagues break down some of my & No & 226 & 62.4 & & \\
\hline 13 & properties & Yes & 136 & 37.6 & 1.58 & $\mathrm{~W}$ \\
\hline & My colloogues slom me for no onnorent reoson & No & 224 & 61.9 & 140 & $\mathbf{W}$ \\
\hline 14 & 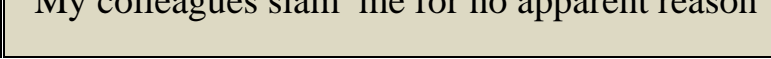 & Yes & 138 & 38.1 & 1.49 & $\mathbf{w}$ \\
\hline & Other students left me out of their group of & No & 185 & 51.1 & 148 & $\mathrm{~W}$ \\
\hline 15 & friends and excluded me & Yes & 177 & 48.9 & & \\
\hline & I had unsuitable comments from some of my & No & 189 & 52.2 & 152 & $\mathrm{~S}_{\mathrm{C}} \mathrm{C}_{\mathrm{C}}$ \\
\hline 16 & colleagues & Yes & 173 & 47.8 & 1.52 & $\mathrm{~S}$ \\
\hline & Some of my colleagues talk about my faults in & No & 175 & 48.3 & 146 & $\mathrm{~W}$ \\
\hline 17 & front of others & Yes & 187 & 51.7 & & \\
\hline
\end{tabular}


University of Thi-Qar Journal Vol.10 No.3 SEP 2015

Web Site: https://jutq.utq.edu.iq/index.php/main Email: journal@jutq.utq.edu.iq

\begin{tabular}{|c|c||c||c||c||c||c||}
\hline 19 & & Yes & 140 & 38.7 & & \\
\hline \multirow{2}{*}{20} & My colleagues interrupt me while I talk & No & 127 & 35.1 & \multirow{2}{*}{1.47} & \multirow{2}{*}{ W } \\
\cline { 3 - 6 } & & Yes & 235 & 64.9 & & \\
\hline \multirow{2}{*}{21} & \multirow{2}{*}{ I had ridiculous dumps of some of my colleagues } & No & 192 & 53 & \multirow{2}{*}{1.69} & \multirow{2}{*}{ S } \\
\cline { 3 - 5 } & & Yes & 170 & 47 & & \\
\hline
\end{tabular}

Table 2 continued ....

$\mathrm{R}=$ Rating; $\mathrm{F}=$ Frequency $; \%=$ Percent $;$ m.s=mean of score $; \mathrm{L}=\mathrm{Level} ; \mathrm{S}=\mathrm{strong} ; \mathrm{W}=$ weak

Strong $=($ mean of score more than 1.5), weak (mean of score less than 1.5)

In light of the statistical mean of score equal to 1.5 , the study results show that the students responses to the bullying domain items indicate that they have strong bullying in many items of the scale.

Table 3:The total level of bullying against victim students

\begin{tabular}{|c|c|c|c|c|c|}
\hline Main domain & $\mathrm{R}$ & $\mathrm{F}$ & $\%$ & $\mathrm{~m} . \mathrm{s}$ & $\mathrm{L}$ \\
\hline \multirow{3}{*}{ Bullying } & Strong & 217 & 59.9 & \multirow{3}{*}{1.79} & \multirow{3}{*}{$\mathrm{S}$} \\
\hline & Weak & 145 & 40.1 & & \\
\hline & Total & 362 & 100 & & \\
\hline
\end{tabular}

R=Rating;F= Frequency; \% = Percent; m.s=mean of score;L=Level;S=strong

This table appear that the overall assessment for the bullying is strong, at mean of score more than 1.5.

\section{Discussion:}

Table (1) appear that $76.5 \%$ of the study subjects are lived in a nuclear family. This can be attributed that they are more likely to be victims of bullying because it makes those low social 


\section{University of Thi-Qar Journal Vol.10 No.3 SEP 2015}

\section{Web Site: https://jutq.utq.edu.iq/index.php/main Email: journal@jutq.utq.edu.iq}

skills and their inability to deal with difficult social situations, this result is supported by the study of Henan (11) who have found that presence a negative significant relationship between school bullying and social skills, also results showed statistically significant differences between the mean scores of high school bullying and low school bullying in social skills in favor of low school bullying .

Results table (1) also appear that $67.1 \%$ of study subjects are lived in family with $4-8$ members, and $55.2 \%$ of them are lived in family with 2-4 children. This can be attributed that whenever the number of children in the family increased that lead to enlarge the responsibilities of parents to follow; guide; teach them the proper techniques and necessary social skills, making them more expected to be victims of school bullying, as well as when the number of elder brothers increased, child become vulnerable to be a victim of bullying because younger children are more likely to be victim of bullying, that's finding agree with results of study conducted by Hakeema(12) in Qatar where the results of this study emphasized that there was an inverse relationship between age and being a victim of bullying behavior .

Concerning parental level of education, results indicates that $61.9 \%$ and $70.2 \%$ of student's fathers and mothers respectively are below preparatory school graduated. This can be attributed that Because most of the parents of the study sample are low level of knowledge, and this produces a failure to teach their children, the skills and behaviors of social correctly, they had low level of knowledge about how to deal with their children to develop child social skills, and how can deal with different situations like bullying in school. This result is supported by study of Osama (13) who aims to find out the relationship between bullying and parental dealings methods with children, his finding showed that the correlation between bullying and methods (neglect, oscillation, tolerance, packets) for the dealing of parental were statistically significant, and that bullying behavior is getting greater with domination, neglect and ignore their parents, while bullying was negatively associated with stylistic Packets and oscillation, the parents more in the style of Packets or the style of the oscillation; boys were less participants in bullying .

Regarding parents occupational status, the results indicate that $48.3 \%$ of fathers are employed, and $84 \%$ of mothers are housewives. This can be attributed that because most of the study sample fathers were employees and this contributed to concern of parents for following up the behavior of their children and guide them in the face of critical social situations, making the children have poor social skills and this makes them vulnerable to be victims of bullying . About mothers, as the most of mothers of the study sample did not received a high level of education and thereby, they became unqualified for the job, and thus reduced opportunity to contact to society from employees and other levels, and this limits the information in the social skills that can be learning to their children and as a result, their children be low social skills .

Finally $47.8 \%$ of the study subjects are reported that their family monthly income is insufficient. This can be attributed that whenever the lack of monthly income of the family becomes less attention to the child, making it a persecutor and neglected, and this affects the 


\section{University of Thi-Qar Journal Vol.10 No.3 SEP 2015}

Web Site: https://jutq.utq.edu.iq/index.php/main Email: journal@jutq.utq.edu.iq

personal behaviors, and this leads to be a victim of bullying, this results shows the students who were being victims of bullying coming from low socioeconomic family.

Figure (1) indicates that more than half of the study sample (57\%) are males, this finding was supported by the study conducted by Paul et al. (14) "important demographic risk factors for bullying victimization and experiencing school hassles". Reported that victimization and school hassles decreased with age and were more common for males than females.

Figures (2):(3) indicates that $34.8 \%$ of the study subjects are at age 11 years old and more than half of the study sample $(59 \%)$ are from $5^{\text {th }}$ grade. This can be attributed that because children aged 11,12 years are natural for the classes in the fifth and sixth grades as opposed to the others age which increased them proportion of study sample, that's mean the younger students more likely to be victims of bullying, this results agree with study done by Hakeema(11) in Qatar where the results of this study emphasized that there is an inverse relationship between age and being a victim of bullying behavior, where young students are more probable to be harassed, and other study conducted by Glenn and Shauna (15) who indicated that as much as $74 \%$ of elementary school students nationwide between the ages of 8 and 11 experiences bullying in their schools .

Figure ( 4 ) appear that most of the subjects are within $2^{\mathrm{ND}}-5^{\text {th }}$ in the arrangement of their brothers and sisters, that's lead us to expect they may be victimized at home from bigger brothers and sisters in the preschool stage and that lead them to be victims in schools, as pointed out by Perren and Alsaker(16)victimized children's lack of friends might render them psychologically and socially at risk, and thus more prone to becoming easy targets .

Tables 2 and 3 shows that the students responses to the bullying domain items indicate that they have strong bullying in many items of the scale, that's include all forms of bullying ( physical, verbal, and indirect or social ) Where their responds to questions by (yes) they were experience forms of bullying repeated 217 times from total 362 in percentage 59.9 and this finding agree with study mad by Hakeema(11) in Qatar, she found that the rate of the victims was the highest recorded (36\%).

Conclusions : There is strong level of bullying against primary school students, student's demographic data have affect on there to be victims of school bullying .

\section{Recommendations:}

The present study recommends using some global intervention programs that have proved effective in addressing the phenomenon to prevent and combat bullying. Consideration to studying the phenomenon of bullying in all levels of education , because of its negative effects on students, and activating the role of the student advisor and social worker to work with the administration, teachers, students and parents to deal with school bullying .

\section{References:}

1. Carroll-Lind, J. School safety: An inquiry into the safety of students at school. (2009). Fromhttp://www.occ.org.nz/publications/reports. 
University of Thi-Qar Journal Vol.10 No.3 SEP 2015

Web Site: https://jutq.utq.edu.iq/index.php/main Email: journal@jutq.utq.edu.iq

2. Swart, E., \& Bredekamp, J. Non-Physical Bullying: Exploring the perspectives of grade 5 girls. South African Journal of Education, (2009).

3. Von Mare'es, N., \& Petermann, F. Bullying in German primary schools: Gender differences, age trends and influence of parents' migration and educational backgrounds. School Psychology International,(2010).

4. David P. Farrington and Maria M. Ttofi .1 .Bullying: Short-Term and Long-Term Effects, and the Importance of Defiance Theory in Explanation and Prevention. Instituteof Criminology, University of Cambridge, Cambridge, UK Victims and Offenders, (2009) .

5. Guillory, Laurice Ann, "An Exploratory Study of Students and Teachers Attitudes Toward Three Types of Bullying: Physical, Verbal and Social Exclusion" (2013). Dissertations.Paper742Retrieved from scholarworks@library.umass.edu

6. RantaK, Kaltiala-HeinoR, Pelkonen M \&Marttunen M Associations between peer victimization, self-reported depression and social phobia among adolescents: the role of comorbidity. J Adolesc (2009).

7. Marano HE. Big. Bad. Bully - includes related article on dealing with bullies cover story. Psychology Today. September/ October,2005.

8. Guerra, N., Williams, K., \&Sadek, S. Understanding bullying and victimization during childhood and adolescence: A mixed methods study. Child Development, (2011).

9. Mustafa Ali Mazloum (2011). Emotional intelligence for bullies and their peers victims in the school environment. Paper presented to the International Conference on the ordinary and special needs. Banha University College of Education, 17-18 / 7.

10. Polit, D.; and Hungler, B.: Nursing research, principles and methods, 6th ed, Baltimore: Lippincott, 1999.

11. Hanan AsaadKhorj: school bullying and its relationship to social skills among primary school students in Jeddah, Saudi Arabia. Journal of Educational and Psychological Sciences Volume 13 Issue December 4, 2012.

12. Hakeema Mohammed. Bullying in the student community. Social Rehabilitation Center (Owain) in Qatar. Al-Raya Journal (2012) .

13. Osama Hamid Hassan. Bullying among children and its relationship to parental treatment methods. The Ministry of Education / open educational college. Educational and Psychological Research Journal (2012).

14. Paul R. Smokowski, Katie L. Cotter, Caroline Robertson, and Shenyang Guo. Demographic, Psychological, and School Environment Correlates of Bullying Victimization and School Hassles in Rural Youth . University of North Carolina at Chapel Hill, School of Social Work, CB No. 3550, 325 Pittsboro Street, Chapel Hill,NC27599-3550,USA. Hindawi Publishing Corporation Journal of Criminology Volume2013.

15. Glenn L. Koonce and Shauna S. Mayo. Effects of Elementary School Students' Gender and Grade Level on Bullying. American International Journal of Social Science Vol. 2 No.7; October 2013. 
University of Thi-Qar Journal Vol.10 No.3 SEP 2015

Web Site: https://jutq.utq.edu.iq/index.php/main Email: journal@jutq.utq.edu.iq

16. Perren and Alsaker. Social behavior and peer relationships of victims, bully-victims, and bullies in kindergarten. J Child Psychology Psychiatry. 2006. 